\title{
Tectonic Stress Field in Central Europe
}

\author{
G. Raxalli - A. E. Scimeidegger (*)
}

Ricevuto il 6 Marzo 1967

\begin{abstract}
Sumparr. - Scheidegger's statistical method for the tectonic interpretation of earthquake fault plane solutions is applied to recently published solutions of earthquakes which occurred in two areas of Central Europe. The results of the calculations show that in Southwestern Germany, east of the eastern border of the Rhine Trench, the tectonic stress state is a tensional one, while in Belgium it seems to be compressional. The $P$ and $T$ directions, however, are very similar in both regions.
\end{abstract}

Riassunto. - Il metodo statistico di Scheidegger per l'interpretazione tettonica del meccanismo dei terremoti all'ipocentro (" earthquake fault plane solutions ") ¿ qui applicato a recenti indagini di sismi occorsi in due differenti regioni dell'Europa centrale. I risultati dei calcoli mostrano che nella Germania sud-occidentale, ad Est del bordo orientale della fossa renana, lo stato tettonico predominante è a carattere tensionale, mentre in Belgio sembra essere a carattere compressionale. Tuttavia le direzioni delle compressioni e delle tensioni sono molto simili in ambedue le regioni considerate.

\section{INTRODUCTION.}

It is a well known fact that the crust of the Earth is subject to a "tectonic" stress state which may vary in its character from region to region. It remains one of the more important problems in geophysies to ascertain the precise nature of this stress state inasmuch as it is not easily possible to measure underground stresses by direct means. Thus, most of our knowledge of tectonic stresses has come from indirect evidence, such as analyses of surface fault patterns, etc.

(*) University of Illinois, Urbana 
One of the most promising alleys for investigating the regional tectonic stresses is based on seismic evidence. A statistical analysis of fault plane solutions of earthquakes yields directly the direction of greatest compression ( $P$-axis), the direction of least compression ( $T$ axis) and the axis of relative motion (normal to the intermediate principal stress $[B]$ axis) in any one area (see Scheidegger, ${ }^{\circ}$ ). This statistical treatment of earthquake fault plane solutions has already given information about the tectonic stress state in various areas of the world [Scheidegger $\left.\left({ }^{9}\right),\left({ }^{10}\right),\left({ }^{11}\right),\left({ }^{12}\right),\left({ }^{13}\right)\right]$. Recently, new sets of fault plane solutions have been ealculated. These news solutions available make now possible a detailed study of some region previously not very well known from the point of view of seismotectonics. In this instance, the present paper deals with two areas of central Europe north of the Alps, namely Southwestern Germany and Belgium.

As to Southwestern Germany, eleren earthquakes which have occurred in the Southern Black Forest, in the southwestern part of the Swabian Jura, and in the western part of the Molasse Basin have been studied. The region in question is roughly confined between $47^{\circ}-49^{\circ} \mathrm{N}$

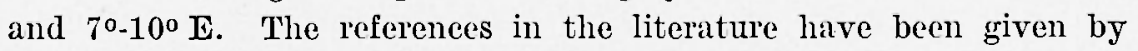
Hordejuk $\left({ }^{8}\right)$, Hiller $\left({ }^{5}\right),\left({ }^{6}\right)$, and Sehneider, Schick and Berckhemer $\left({ }^{14}\right)$. The directions of the $P, T$, and $B$ axes have been calculated for each one of these earthquakes. The fault plane solutions are listed in Table I jin the standard form employed by Fara $\left(^{1}\right)$. The key to the literature references is as follows:

\section{1: Hordejuk $\left({ }^{8}\right)$;}

2,3: Hiller $\left({ }^{5}\right),\left({ }^{6}\right)$;

4,5,6,7,8,9,10,11: Schneider, Schick and Berckhemer ( $\left.{ }^{14}\right)$. 'For the first three earthquakes, planes I and II have also been calculated. In seven out of the eight earthquakes studied by Schneider, Schick and Berckhemer ("), the $B$ axis has beenjassumed to be vertical, and accordingly, the $P$ and $T$ axes have been assumed to be horizontal, since the $\Lambda$ uthors give no information about the dip of the $B$ axis, but only the projections of the two nodal lines on the surface of the Farth and the horizontal directions of the $P$ and $T$ axes. Sometimes the nodal lines are not perpendicular to each other; this can be explained by a slight tilt of the force system. Another case in which the nodal lines were not perpendicular has been studied by Caloi $\left({ }^{2}\right)$. This earthquake occurred on October 18, 1936, and its epicenter was located near the town of Bellumo, in north-eastern Italy; its epicentral 
Table I - Fault plane solutions of earthquakes in Southern Germany

\begin{tabular}{|c|c|c|c|c|c|c|c|}
\hline Date & Epicenter & $P$ & $T$ & P & Plane I & Plane Il & No. \\
\hline 16.11 .11 & $48.3 \mathrm{~N} 009.1 \mathrm{E} 00$ & N75W38 & S60E5l & N21E07 & N68W84 & N63E $10 * \mathrm{D} 11$ & 1 \\
\hline 08.02 .33 & $48.8 \mathrm{~N} 008.2 \mathrm{E} 00$ & N25W00 & N65E00 & NO0E90 & S70E 90 & N20E $90 \mathrm{~S}$ & 2 \\
\hline 27.06 .35 & $48.1 \mathrm{~N} 009.4 \mathrm{E} 00$ & S05E00 & N85E00 & N00E90 & N50W90 & N61E 90 S 01 & 3 \\
\hline 02.05 .43 & $48.3 \mathrm{~N} 009.0 \mathrm{E} 00$ & N40W00 & N46E00 & N00E90 & & & 4 \\
\hline 28.03 .60 & $48.3 \mathrm{~N} 009.0 \mathrm{E} 00$ & $\mathrm{~N} 43 \mathrm{~W} 00$ & N43E00 & NoOE 90 & & & $\tilde{5}$ \\
\hline 19.04 .61 & $48.1 \mathrm{~N} 009.0 \mathrm{E} 00$ & $\mathrm{~N} 28 \mathrm{~W} 00$ & N63E00 & No0E 90 & & & 6 \\
\hline 28.04 .61 & $47.7 \mathrm{~N} 007.9 \mathrm{E} \quad 00$ & N38IV00 & N51E00 & N00E90 & & & 7 \\
\hline 27.03 .65 & $48.1 \mathrm{~N} 009.5 \mathrm{E} 00$ & N02W00 & N88E00 & NoOE 90 & & & 8 \\
\hline 30.03 .65 & $48.1 \mathrm{~N} 009.5 \mathrm{E} 00$ & N03W00 & N87E00 & N00E90 & & & 9 \\
\hline 25.05 .65 & $48.1 \mathrm{~N} 009.5 \mathrm{E} 00$ & N01W00 & N89E00 & N00E90 & & & 10 \\
\hline 19.09 .65 & $47.9 \mathrm{~N} 008.2 \mathrm{E} \quad 00$ & $\mathrm{~S} 23 \mathrm{~W} 10$ & $\mathrm{~N} 23 \mathrm{E} 80$ & S67E00 & & & 11 \\
\hline
\end{tabular}


coordinates are approximately $16^{\circ} \mathrm{N}$ and $12^{\circ} \mathrm{E}$. It is interesting to note that the horizontal projections of the $P$ and $T$ axes are $\mathrm{N} 29^{\circ} \mathrm{W}$ and $\mathrm{N} 61^{\circ} \mathrm{E}$ respectively, i.e. very similar to those of southwestern Germany and Belgium. In earthquake (11) the $B$ axis is horizontal, and the dips of the $P$ and $T$ axes have been calculated on the basis of a method proposed by Hiller $\left({ }^{7}\right)$.

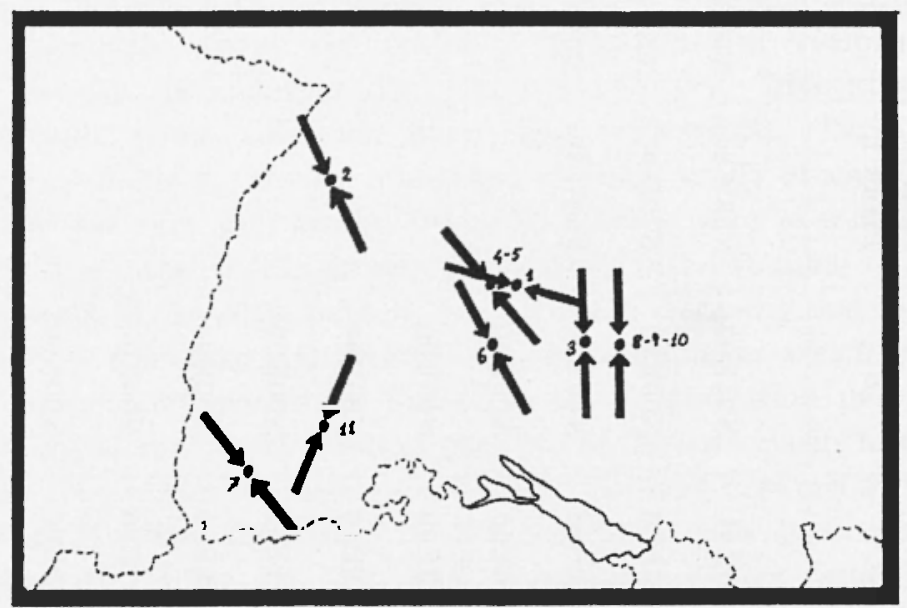

Fig. 1 - P-directions for earthquakes in Southwestern Germany.

Fig. 1 shows the $P$ directions for each of these earthquakes which have occurred in Southwestern Germany.

The second region considered is Belgium. The area under consideration is roughly confined between $50^{\circ}-52^{\circ} \mathrm{N}$ and $4^{\circ}-6^{\circ} \mathrm{E}$. The data have been calculated from information given in papers by Ahorner and Van Gils ( $\left.{ }^{1}\right)$, and Van Gils ${ }^{\left({ }^{5}\right.}$ ). Three earthquakes have been taken into account, but, since in the earthquake of December 15, 1965, the foreshock and the main shock showed a completely reversed ground motion direction, four cases are listed in Table II. The key to literature references is:

\section{2: Ahorner \& Van Gils $\left({ }^{1}\right)$;}

13,14,15: Van Gils $\left({ }^{15}\right)$.

Cases listed as (13) and (14) refer respectively to the foreshock and to the main shock of the above mentioned earthquake of December 15, 1965. For earthquake (12), planes I and II have also been calculated. The $B$ axis has been assumed to be vertical in (13), (14), 
'Iable $\|$ - Fault plane solutions of eartiquakes in l3elgium.

\begin{tabular}{|c|c|c|c|c|c|c|c|}
\hline Date & Epicenter & $P$ & $T$ & $B$ & Plane I & Plane I & No. \\
\hline 25.06 .60 & $51.2 \mathrm{~N} 005.7 \mathrm{E} 004.2$ & NOOE 00 & N90E32 & N90W5s & N90E 77 & NooE $00^{*}$ & 12 \\
\hline 15.12 .65 & $50.2 \mathrm{~N} 004.0 \mathrm{E} 004.4$ & N57W00 & N33E00 & No0E90 & & & 13 \\
\hline 15.12 .65 & $50.2 \mathrm{~N} 004.0 \mathrm{E} 004.4$ & N33E00 & N57W00 & No0E 90 & & & 14 \\
\hline 21.12 .65 & $50.4 \mathrm{~N} 005.3 \mathrm{E} 004.4$ & N66W00 & N24E00 & No0E 90 & & & 15 \\
\hline
\end{tabular}


(15). Since these solutions are based upon recordings from Belgian stations only, they have no exagrerate claim of accuracy.

Fig. 2 shows the $P$ directions for each case.

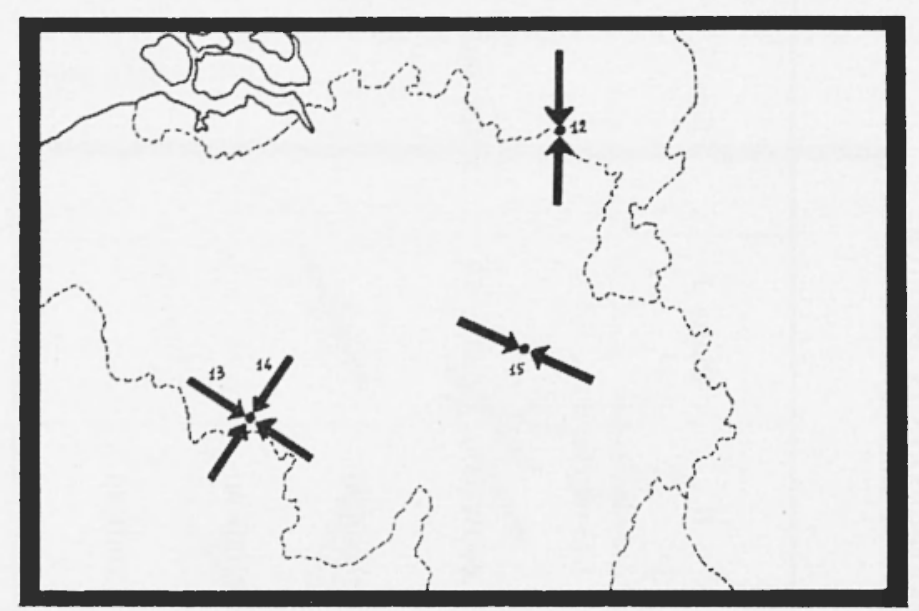

Fig. 2 - P-directions for Belgian earthquakes.

\section{'TREA'IMEN'I OF DA'TA.}

The fault plane solutions listed in Tables 1 and 2 have been treated by a statistical method developed by Scheidegger $\left({ }^{9}\right)$; the best fitting $P, T$, and $B$-normal axes have been calculated by an eigenvalue technique with the help of the University of Illinois IBNI 70941.101 Computer System. The $B$-normal axis has the sense of direction of motion; if it is more or less in the same direction of the best $P$ axis, the tectonic area is a compressional one, in the other case, we are dealing with a tensional tectonic region.

Tablo III - Results of calculations.

\begin{tabular}{|c|c|c|c|c|}
\hline Area & $\begin{array}{l}\text { No. } \\
\text { of Quakes }\end{array}$ & Best $P$ & Best $T$ & Motion axis \\
\hline Southwestern Germany & 11 & N19W 01 & $\mathrm{~N} 70 \mathrm{E} \quad 04$ & S60W 01 \\
\hline Belgium & 4 & N33IV 00 & N51E 10 & No0E 00 \\
\hline
\end{tabular}


The results of the statistical calcultations are shown in Table III. The mean stress systems in Southerwestern Germany and Belgium are plotted in Fig. 3.

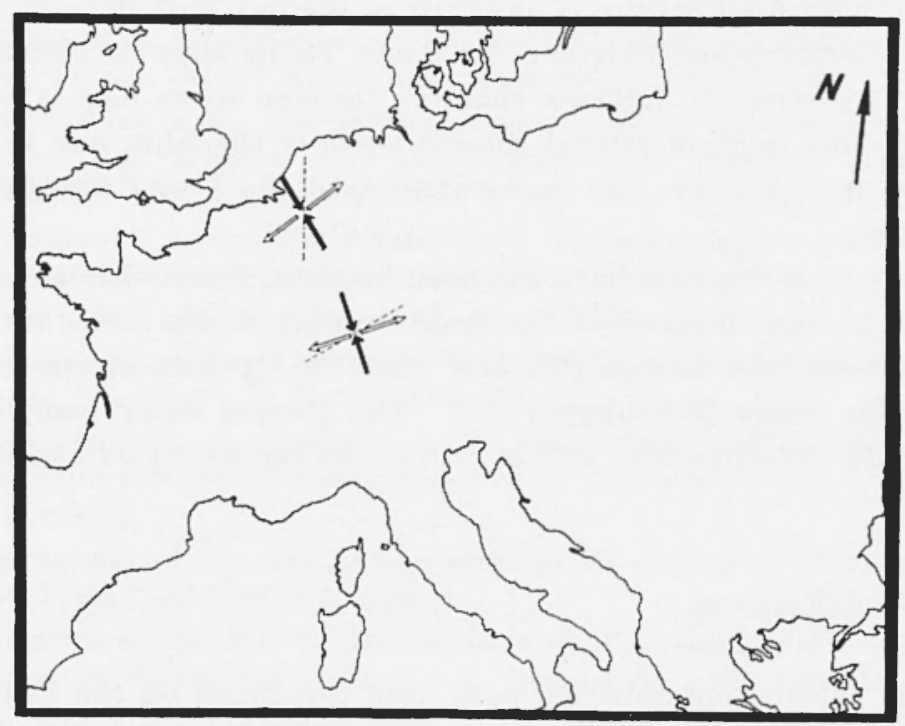

Fig. 3 - Mean stress systems in Southwestern Germany and Belgium (solid arrow: $P$-axis; blank arrow: $T$ axis; dotted line: motion direction).

\section{RESUL'TS.}

We shall consider separately the two geographical areas under consideration. In Southwestern Germany, all earthquakes under consideration have occurred in the region immediately east of the eastem border of the Rhine Trench, namely in intensely faulted areas (as the Southern Black Forest, and the western part of the Swabian Jura near the Hohenzoller'n Trench). Individual fault plane solutions show that both strike-slip and dip-slip motions are present in this zone [Schneider, Schick and Berckhemer $\left({ }^{14}\right)$ ]. The result of the statistical calculations points out that the stress system is a tensional one (the motion axis nearly coincides with the best fitting $T$ axis). This is not unexpected in a border zone of a trench, and therefore this result is consistent with what one may reasonably infer from purely geological considerations.

As regards the Belgian region, it is to be again pointed ont that the fault plane solutions are based on data from few seismice stations, 
and, moreover, that the number of earthquakes is very small. Anyway, the result indicates that the area is one of compressional tectonic stress (the motion axis is closer to the $P$ axis than to the $T$ axis).

An interesting feature is observed in the fact that in both, Southwestern Germany and Belgium, the $P$ and $T$ directions are almost identical. This seems to indicate that the tectonic stress field is more or less the same in all of central Europe north of the Alps, and that it is only the intensity (i.e. the predominance) of the $P$ or $T$ direction that is diflerent.

Very recently, new light has been brought, from seismic evidence, into the tectonic features of the Mediterranean region [Constantinescu, Ruprechtova, and Enescu $\left({ }^{3}\right)$ ], and into the present stress state of the Alpine range [Scheidegger $\left({ }^{13}\right)$ ]. The present study complements these other investigations with regard to the remaining part of Europe.

\section{ACKNOWLEDGMEN'S'S.}

The calculations reported here were performed on the University of Illinois IBM 7094-1401 computing system operating under a grant from the National Science Foundation. The writers are indebted to Professor Berckhemer of Frankfurt for letting them have a copy of the paper on fault plane solutions of earthquakes in Baden-Württemberg prior to its publication.

\section{REFERENCES}

(1) Ahorner L., Van Gils J. M., Das Erdbeben vom 25 Juni $1960 \mathrm{im}$ Belgischnederländischen Grenzgebiet. Acad. Royale de Belgique, "Bull. Cl. Sciences", Serie Geopliys., 67, (1964).

(2) Calor P.. Ricerche su terremoti ad origine vicina. Scosse del Cansiglio dell'Ottobre 1936. "I La Ricerca Scientifica", 9, 2, 1.41, (1938).

(3) Constantisescu I., Ruprechtova L., Enescu D., Mediterranean alpine earthquale mechanisms and their seismotectonic implications, "Geopl. J. R. Astr. Soc. ", 10, 347-368, (1966).

(') HARA H. D., A new catalogue of earthquake fault plane solutions, "Bull. Seism. Soc. Am.", 54, 1491-1517, (1964):

(5) Hillen W., Der Herd des Rastatter Bebens am 8 Februar 1933, "Gerl. Beitr. zur Geoph.", 41, 2, 170-180, (1934). 
(i) Hiller W., Das oberschwäbische Erdbeben am 27. Juni 1935. "Württ. Jb. für Statistik u. Landeskde ", Jng. 1934/35, 209-226, (1936a).

(7) Hiller W., Das Erdbeben im nörllichen s'chwarzwald am 30. Dezember 1935, "Seism. Ber. Württbg. Erdbebenw". Jg. 1935, (1936b).

${ }^{8}$ ) HoRdejuk J., Charakterystyka dynamiczna ogniska Trzesienia ziemi z dnia 16. 11. 1911, "Acta geoph. Polonica", 5, 2, 103-109, (1957).

(") Scheidegger A. E., The tectonic stress and tectonic motion direction in Europe and Western Asia as calculated from earthquake fault plane solutions, "Bull. Seism. Soc. Am.", 54, 1519-1528, (1964).

${ }^{10}$ Scinempgger A. E., The tectonic stress and tectonic motion direction in the Pacific and adjacent areas as calculated from earthquake fault plane solutions, "Bull. Seism. Soc. Am.", 55, 147-152, (1965a).

(') ScIIEIDEgGer A. E., Grosstektonische Bedeutung von Erdbebenherdmechanismen, "Z. Geoph.", 31, 300-312, (1965b).

${ }^{(12)}$ Scimeidegger A. E., Tectonics of the artic seismic bett in the light of faultplane solutions of earthquakes, "Bull. Seism. Soc. Am.", 56, 241 . 245, (1966).

(13) Scheidegger A. E., The tectonic stress in the vicinity of the Alps, " $\mathrm{Z}$. Geophysik" 33, 167-181, (1967).

(14) Schneider G., ScHick R., Berckineuer H., Fault-plane solutions of earthqualies in Baden-Württemberg, "Z. Geophysik", 32, 383-393, (1966).

${ }^{\left({ }^{15}\right)}$ VAN GiLs J. M., Les tremblements de terre des 15 et 21 Décembre $196 \overline{\mathrm{en}}$ Belgique. Acad. Royale de Belgique. "Bull. Cl. Sciences", Série Geoph. 74, 101-107, (1966). 